\title{
A CARBON-NANOTUBES-BASED HEATING FABRIC COMPOSITE FOR AUTOMOTIVE APPLICATIONS
}

\author{
TKANINA S KOMPOZITNO PREVLEKO NA OSNOVI OGLJIKOVIH \\ NANOCEVK ZA SEGREVANJE AVTOMOBILSKIH SEDEŽEV
}

\author{
Vinko Grm ${ }^{1,2}$, Daniela Zavec ${ }^{3}$, Goran Dražićc, ,* $^{*}$ \\ 1ETRA d.o.o., Svetelka 5, 3222 Dramlje, Slovenia \\ 2Jožef Stefan International Postgraduate School, Jamova 39, 1000 Ljubljana, Slovenia \\ 3 Titera d.o.o., Mondova 59, 2212 Sentilj v Slovenskih Goricah, Slovenia \\ ${ }^{4}$ National Institute of Chemistry, Hajdrihova 19, 1000 Ljubljana, Slovenia
}

Prejem rokopisa - received: 2019-10-04; sprejem za objavo - accepted for publication: 2020-07-15

doi:10.17222/mit.2019.238

\begin{abstract}
The preparation and properties of a composite fabric material containing carbon nanotubes and polyaniline with a suitable electrical conductivity to be potentially used as a resistive heating element in car seats are reported. Three different materials that are the most commonly used fabrics in cars, i.e., leather, cotton canvas and artificial leather, were screen-printed on the bottom side of the fabric with flexible and highly conductive single-wall carbon nanotubes and polyaniline-containing coatings. The thickness and accordingly the electrical conductivity of the coatings were tailored with the number of screen-printed layers. The conductivity was explained with the percolation model, where the percolation threshold was found to be at 8 screen-printed layers. The morphology and uniformity of the coatings were studied with electron-microscopy techniques. Long interconnected bundles of carbon nanotubes and polyaniline fibres made possible a suitable electrical conductivity, even when the fabric was stretched. When heated, the temperature distribution across the surface was measured with an IR camera and was uniform to within a few degrees centigrade. Samples of the prepared fabric material enabled uniform heating up to $50{ }^{\circ} \mathrm{C}$ within two minutes using around $3 \mathrm{~W}$ of electrical power.

Keywords: single-wall carbon nanotubes, polyaniline, electrically conductive fabrics, heating textiles
\end{abstract}

$\mathrm{V}$ delu je opisana priprava in lastnostih tkanine z električno prevodno prevleko na osnovi kompozita z enostenskimi ogljikovimi nanocevkami in polianilinskimi vlakni za segrevanje avtomobilskih sedežev. Kot osnovo smo uporabili tri najbolj razširjene tkanine v avtomobilski industriji, pravo usnje, bombažno platno in umetno usnje, na katere smo s spodnje strani s sitotiskom nanesli kompozitno prevleko. Debelino prevleke in s tem tudi električno prevodnost smo uravnavali s številom posameznih nanosov. Ugotovili smo, da se prevodnost da opisati s perkolacijskim modelom, kjer je bil perkolacijski prag pri 8 nanosih. Morfologijo in enakomernost nanosov smo raziskovali z različnimi metodami elektronske mikroskopije. Dolgi, med seboj prepletajoči snopiči ogljikovih nanocevk in polianilinskih vlaken so omogočili zadostno električno prevodnost tudi $\mathrm{v}$ primeru raztezka tkanine. Hitrost in enakomernost segrevanja smo zasledovali z IR kamero, vzorci so se relativno enakomerno segreli do $50{ }^{\circ} \mathrm{C}$ v času dveh minut pri $3 \mathrm{~W}$ električne moči.

Ključne besede: enostenske ogljikove nanocevke, polianilin, električno prevodne tkanine, tekstilije za ogrevanje

\section{INTRODUCTION}

Environmental requirements in recent decades have led to intensive research in the area of minimizing energy consumption. In the field of transport, electrical vehicles are one of the possibilities to reduce the carbon footprint and there are numerous studies regarding their efficiency. ${ }^{1}$ In many parts around the globe, where winters can be quite long and cold, heated seats in cars are one of the major electric energy consumers, and consequently there is an accelerated research and development of new materials and approaches that would be more energy efficient. ${ }^{2}$

The development of cars and other motorized vehicles (trucks and busses) in the next 10 years will be focused on zero-emission and increased safety that will require the use of intelligent materials for different

*Corresponding author's e-mail: goran.drazic@ki.si (Goran Dražić) sensors, actuators and functional assemblies that will enable new and demanding functions. ${ }^{3}$ The microclimate control in cars also becomes an issue of the car's safety because properties such as the temperature, temperature gradient, humidity, air quality, etc. inside the cabin have an influence on the attention and comfort of the driver or passengers. The heating of car seats has thus become standard equipment in most, even lower-priced, cars. ${ }^{4}$

Car-seat heating is nowadays realized through the use of discrete resistive elements based on metal wires or carbon fibers. ${ }^{5}$ The consumption of electrical energy is relatively high and might be a problem in the case of electric cars used in cold weather, where the performance of Li-ion batteries is also reduced. In recent years, there have been many reports of using conductive films based on carbon nanotubes as heating elements, but they are still in the prototype phase..$^{2,6-8}$ The increased efficiency of such heating is due to a better contact between the heating area and the driver or passenger, smaller electrical currents, lower heat capacity and the 
V. GRM et al.: A CARBON-NANOTUBES-BASED HEATING FABRIC COMPOSITE ...

Table 1: Some properties of the selected materials used in the study, A - longitudinal and B - transversal direction

\begin{tabular}{|c|c|c|c|c|c|c|c|}
\hline \multirow{2}{*}{\multicolumn{2}{|c|}{ Material }} & \multirow{2}{*}{$\begin{array}{l}\text { Surface mass } \\
\qquad\left(\mathrm{g} / \mathrm{m}_{2}\right)\end{array}$} & \multirow{2}{*}{$\begin{array}{l}\text { Thickness } \\
\text { (mm) }\end{array}$} & \multicolumn{2}{|c|}{$\begin{array}{l}\text { Ultimate tensile strength } \\
(\mathrm{MPa})\end{array}$} & \multicolumn{2}{|c|}{$\begin{array}{l}\text { Tensile strain at the breaking } \\
\text { point }(\%)\end{array}$} \\
\hline & & & & A & $\mathrm{B}$ & A & $\mathrm{B}$ \\
\hline 1 & Leather & 640.1 & 0.98 & 20.8 & 20.5 & 56.7 & 49.7 \\
\hline 2 & Cotton canvas & 320.0 & 0.43 & 18.9 & 34.2 & 14.8 & 15.1 \\
\hline 3 & Artificial leather & 680.0 & 0.91 & 5.6 & 4.2 & 27.3 & 70.9 \\
\hline
\end{tabular}

time required to reach the desired temperature and comfort level.

Carbon nanotubes (CNTs) have a relatively high electrical conductivity, so integrated with textile materials they can be used as electromagnetic shields ${ }^{9,10}$ and heating elements. ${ }^{11,12}$ The preparation of conductive coatings using techniques such as dip-coating, screen printing, spraying or ink-jet printing is not complicated and technologically demanding. In composite materials using different volumes of conductive material mixed with the nonconductive matrix, so that the system is over the percolation threshold $1^{3,14,15}$ the electrical conductivity can be tailored. Recently, it has been found that electrical currents in carbon nanotubes (and graphene) can couple to the vibrational modes of neighboring material, heating it remotely, meaning that carbon nanotubes are not heated directly, they just induce the heating of the matrix. ${ }^{16}$

In order to evenly distribute the heat over the bodycontact area of the automotive seats we planned to apply the heating coatings to the bottom of the textile over the whole sitting area of the seat. In this work we report on the fabrication and properties of heating fabric material covered with carbon single-walled nanotubes based on a composite coating using screen printing. Different formulations and additives, like highly electrical conductive polyaniline fibers and silver nanoparticles, were studied. Silver was added to improve the antibacterial characteristics of the material. Composite coatings were applied to three different fabric materials that are commonly used in car-seat production, i.e., leather, cotton canvas and artificial leather. The electrical conductivity and consequently the heating properties were tailored with the thickness (number) of the coatings. The electrical properties were measured as a function of the tensile strain that those materials are usually exposed to during their use. Heating rate and temperature uniformity over the whole heated area were also studied.

\section{EXPERIMENTAL PART}

Three materials, commonly used as car-seat covers, i.e., real leather, cotton canvas and artificial leather, were selected and prepared for further experiments and testing. The properties of the materials are summarized in Table 1 and the optical micrographs of the top-surfaces are presented in Figure 1. The producers of the materials were Bedsi, Italy in the case of leather, Creative Company, Denmark for cotton canvas and Sava Kranj, Slovenia for artificial leather.

The ultimate tensile strength and strain at the breaking point of the studied fabrics was measured on $2.5 \mathrm{~cm} \times 20 \mathrm{~cm}$ samples using an Instron 5567 tensile and compression tester (Norwood, MA, USA).

The basic approach for heating the fabric preparation was screen printing of a single-wall carbon nanotube (SWCNT)-based layer with suitable electrical, thermal and mechanical properties on the back side of commonly used fabrics. Pure SWCNT-based coatings did not have suitable electro-thermal properties. To improve the electrical conductivity, polyaniline was added to the carbon nanotubes. Polyaniline is a polymer with a high electrical conductivity and belongs to the group of conductive polymers that are sometimes called "organic metal" because their electrical conductivity is similar to copper or silver. ${ }^{17}$ They have interchangeable double and single bonds in the molecule, i.e., conjugated double bonds. When the polymer with conjugated double bonds
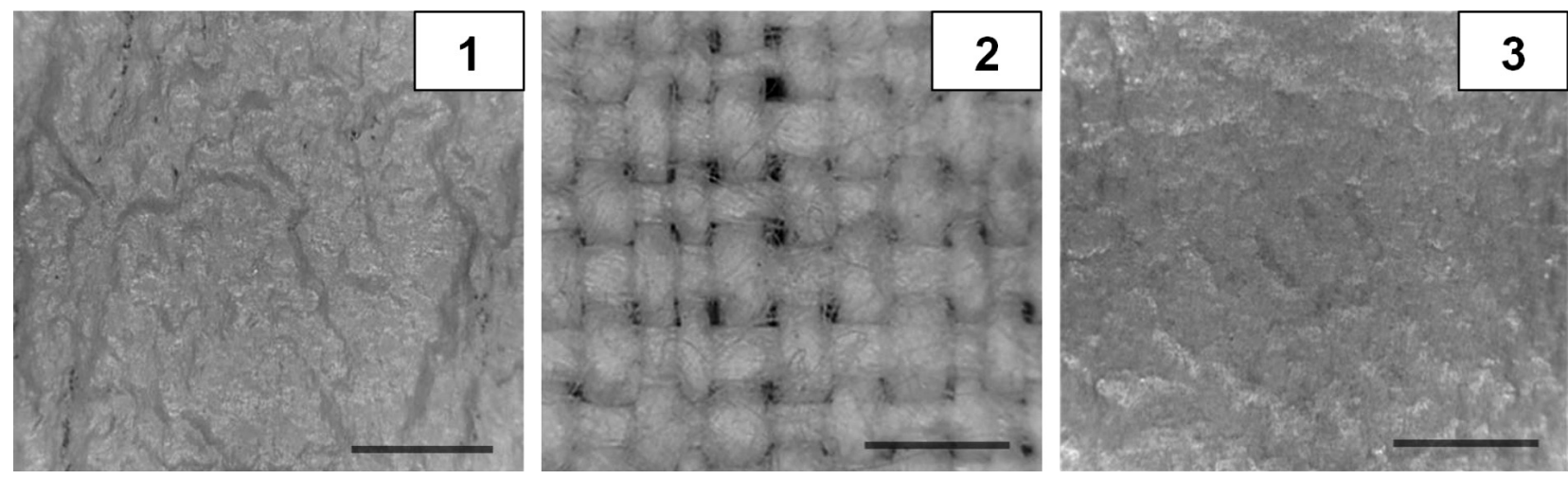

Figure 1: Optical micrographs of fabric samples surfaces. Marker represents $2 \mathrm{~mm}$. 1 - leather, 2 - cotton canvas, 3 - artificial leather 
is oxidized, the electron holes are generated which, under the influence of external electrical field, move through $\pi$-electron orbital conjugated double bonds. ${ }^{18} \mathrm{~A}$ small quantity of nano-sized silver particles was also added in some compositions to improve the anti-bacterial properties of the fabric.

Optimized suspensions used for screen printing of the coatings contained besides $15 \mathrm{w} / \%$ of carbon nanotubes 5 w/\% of polyaniline (Sigma Aldrich, USA) and silver nanoparticles (0-1\%, Ferro GmbH, Hanau, Germany), all dispersed in ethoxypropyl acetate based adhesive binder (80 w/\%, Eco Plastigloss, series FPT, Sirpi SRL, Milano, Italy).

Among the carbon nanotubes we tested, the TUBALL Matrix 201 single-wall CNT (OCSiAl, Leudelange, Luxembourg) were found to give the best results. The characteristics of the carbon nanotubes TUBALL Matrix are listed in Table 2.

Table 2: Properties of Tuball Matrix 201 single-wall CNT used in the study

\begin{tabular}{|c|c|c|c|}
\hline Description & Unit & Value & Method used \\
\hline Carbon content & volume $\%$ & 85 & TGA \\
\hline $\begin{array}{c}\text { Carbon nanotubes } \\
\text { (CNTs) }\end{array}$ & volume $\%$ & 75 & TGA \\
\hline Number of walls & & $1-2$ & TEM \\
\hline Outer diameter CNT & $\mathrm{nm}$ & $1-2$ & RAMAN, TEM \\
\hline Aspect ratio & & $50+$ & RAMAN, TEM \\
\hline Impurities (metals) & volume $\%$ & 15 & EDX, TGA \\
\hline BET surface & $\mathrm{m}^{2} / \mathrm{g}$ & 400 & BET \\
\hline
\end{tabular}

Figure 2 displays TEM micrographs of single-wall carbon nanotubes (SWCNTs) and polyaniline fibers used in this study. The black, spherical, 10-nm-sized nanoparticles are iron, most probably used as a catalyst in the synthesis of the carbon nanotubes.

The coating procedure was carried out with industrial screen printers (models Fusion and Chameleon, M\&R, Roselle, IL, USA) on samples $20 \mathrm{~cm} \times 20 \mathrm{~cm}$ in size. The gradation of the sieves was adjusted to the viscosity of the suspension. Different numbers of successive printings (layers, 1 to 14 ) were applied in order to tailor the desired electrical properties.
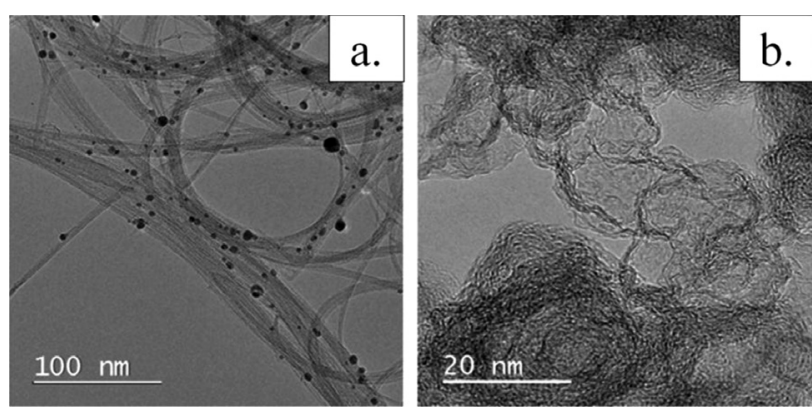

Figure 2: TEM micrographs of: a) bundles of single-wall carbon nanotubes (SWCNTs) and b) polyaniline fibres used in the present study
For electrical and temperature measurements an electronic measuring system was set-up (Figure 3). The applied (direct current) voltages used were in the range up to $28 \mathrm{~V}$, the contacts with the impregnated fabric were realized as two sets of 10-cm-long copper ribbons where the fabric was fixed in between. Besides the electrical current measurements a set of six temperature sensors (resistance temperature detectors - RTD) were uniformly set over the heated area of the fabric and the temperatures were simultaneously measured as a function of time.

In a separate set-up the temperature distribution over the heated area as a function of time was monitored with an IR camera (model E6, Flir systems, Wilsonville, OR, USA).

The influence of tensile stress (resulting in elongation of the samples) on electrical properties was measured with a set-up where $20 \mathrm{~cm} \times 20 \mathrm{~cm}$ fabric samples were fixed on one end and stretched on the other end with a simultaneous measurement of the electrical current and the tensile force using a dynamometer.

Microstructural investigations were carried on a Jeol ARM 200 CF Cs-probe corrected scanning transmission electron microscope and FEI Helios Nanolab 650i dual-beam FIB system.

\section{RESULTS}

\subsection{Microstructure of the surface coatings}

After screen printing the surface of the sample fabric material was examined with a FIB (SEM). In Figure 4 the coated surface of the cotton canvas (14 layers obtained with 14 successive screen-printing steps) is displayed at different magnifications. The roughness of the surface originated from the base material. There is a substantial amount of pores, which enables the "breathability" of the textile. At higher magnification it can be noticed that bundles of SWCNT are interconnected and forming loops.

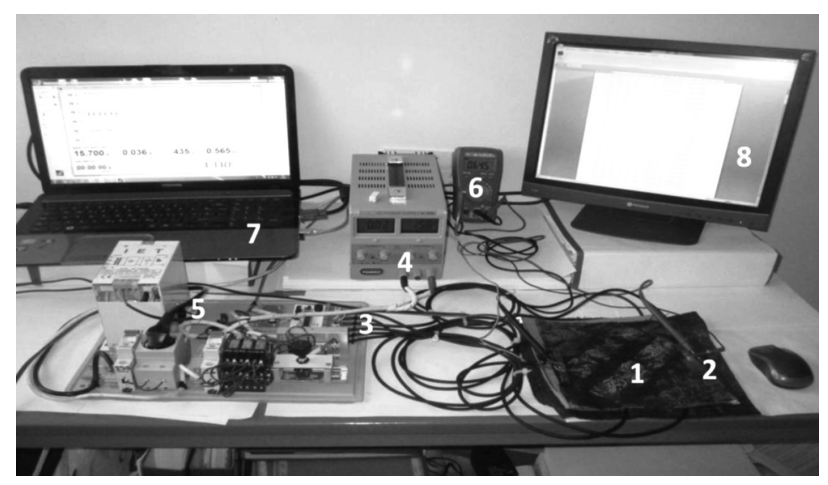

Figure 3: Experimental set-up for electrical and thermal measurements. 1 - tested fabric material, 2 - electrical contacts, 3 - outputs of 6 thermal sensors, 4 - programmable voltage generator, 5 - A/D converter (temperature and current measurements), 6 - backup voltmeter, 7 - computer recording all data, 8 - second monitor displaying measured values 


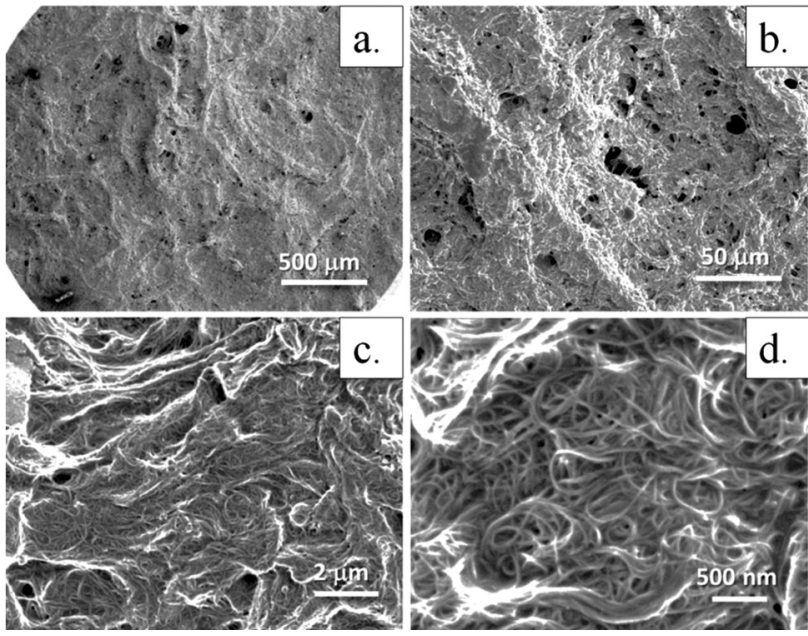

Figure 4: SEM micrographs of cotton canvas sample impregnated with SWCNT and polyaniline-based coating. Surface of canvas is uniformly covered with the composite material. Some pores in the coating are also present $(\mathrm{a}, \mathrm{b})$. Long CNT bundles are interconnected and forming loops $(\mathrm{c}, \mathrm{d})$

To improve the anti-bacterial properties of the fabric we also prepared the composition where $1 \mathrm{w} / \%$ of silver nanoparticles was added. From the SEM images (Figure 5) it was concluded that silver nanoparticles are forming up to 200-nm-sized aggregates, which are uniformly distributed over the entire surface.

The thickness of the coatings (after 10 successive screen-printings) was around $2 \mu \mathrm{m}$, as determined by FIB cross-sectioning (Figure 6). We can estimate that the average thickness of one coating is around $200 \mathrm{~nm}$, individual coatings and interfaces between cannot be seen, indicating that the individual layers are firmly bound together. The Pt layer at the top of CNT coatings is used for surface protection during the FIB crosssectioning.

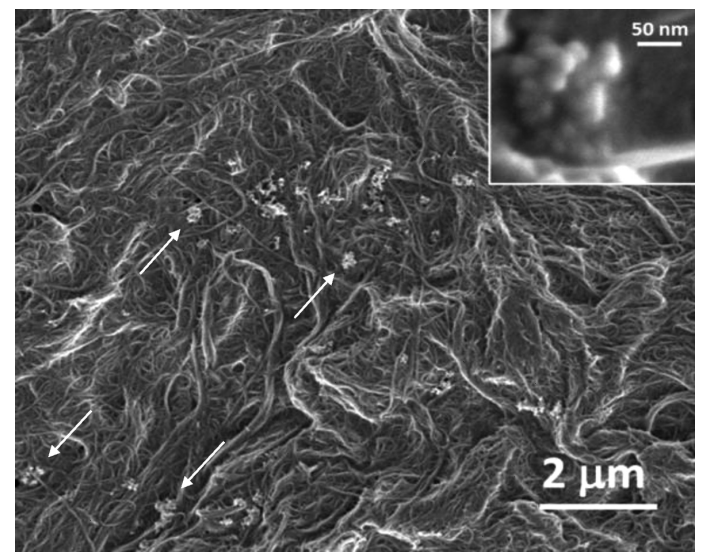

Figure 5: SEM micrographs of cotton canvas impregnated with SWCNT, polyaniline and nanoparticles of silver. Nanoparticles are forming small aggregates (indicated by arrows) which are more-or-less uniformly distributed over the surface. Inset is a detail of Ag aggregate consisting of 20-50-nm-sized spherical silver nanoparticles

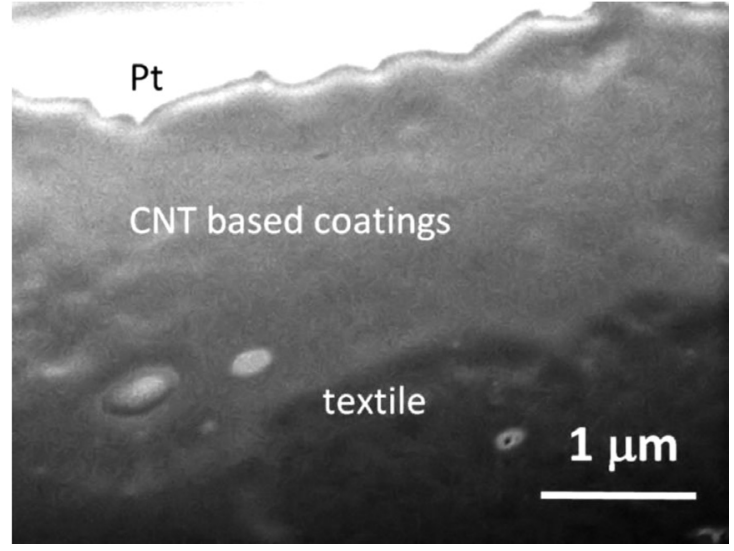

Figure 6: SEM micrograph of FIB cross-section of cotton canvas coated with ten CNT-based coatings. Pt layer was deposited at the top surface as a protective layer before X-sectioning with $\mathrm{Ga}$ ions

\subsection{Electrical and thermal properties}

\subsubsection{Percolation model of electrical conductivity}

It was expected that the electrical conductivity of our system should follow a percolation model, so we first performed a study of the influence of the number of layers (number of successive screen-printing procedures) on the electrical conductivity. In Figure 7 the diagram of sheet conductivity vs. number of layers is displayed. The shape of the curve is characteristic for percolation where we estimated that the percolation threshold is at around 8 layers. The measurements of electrical current were performed on $20 \mathrm{~cm} \times 20 \mathrm{~cm}$ samples at $24 \mathrm{~V}$ with a setup described earlier. Crossing the percolation threshold we observed 2 to 5 folds increase in the sheet conductivity.

In the next experiments we tested the linearity of the current vs. voltage. We performed measurements on all three fabric materials (with 14 layers) as shown in Figure 8. In all cases samples approximately obey Ohm's law. From the slope of the lines we calculated the

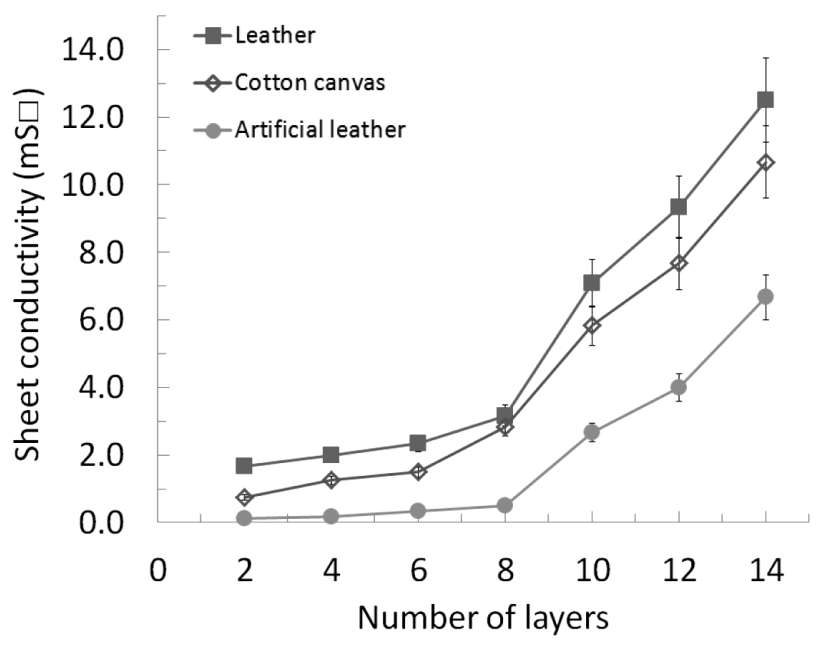

Figure 7: Diagram of sheet conductivity vs. number of layers in samples used for estimation of percolation threshold, measured at $24 \mathrm{~V}$ 


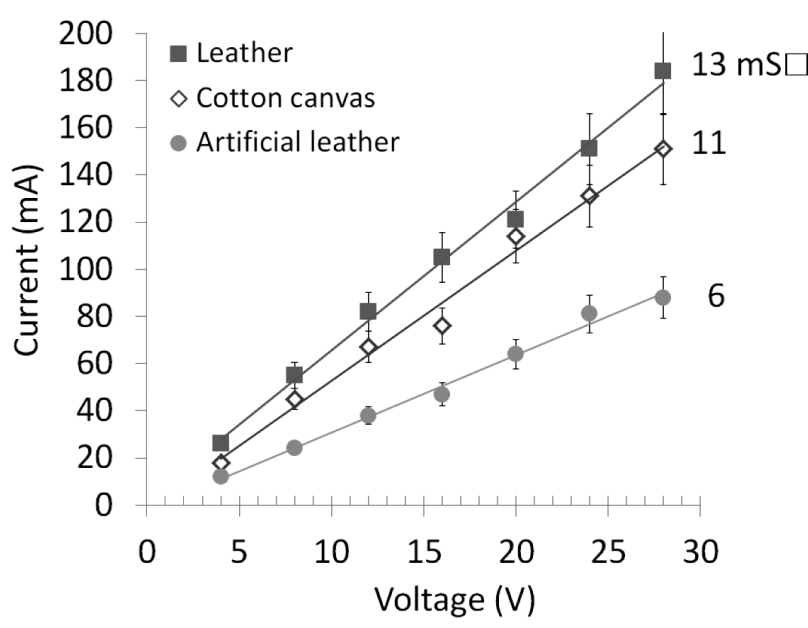

Figure 8: Electric current as a function of applied voltage for samples with 14 layers. Samples size was $20 \times 20 \mathrm{~cm}$. Numbers beside the curves are the calculated sheet conductivity in $\mathrm{mS}$

sheet conductivity (in $\mathrm{mS}$ ) and found that the best conductors are the samples based on leather and cotton canvas.

\subsubsection{Electrical conductivity at tensile strain}

In order to obtain the results that correspond to the realistic conditions at which car seats are used, we performed electrical conductivity measurements of the fabrics under a tensile load. The results are given in Figure 9 and Figure 10 for the cotton-canvas-based fabric.

A special set-up was made on which we were able to load the fabric with a tensile force of up to $400 \mathrm{~N}$. With increasing tensile force we observed as expected, up to $6 \%$ elongation of the samples and reduction of the sheet conductivity. The force-elongation curve shown in Figure 9 has a typical $\mathrm{J}$-shape that is characteristic for cotton fabric and biological tissues and is similar to the stress-strain curves of the elastomeric polymers. ${ }^{19,20}$

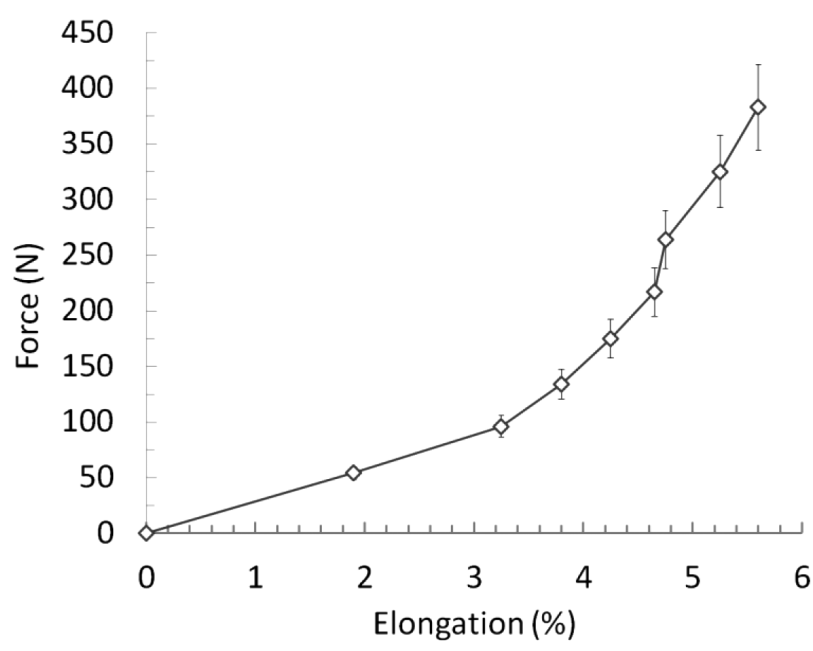

Figure 9: Tensile force - strain curve for cotton canvas sample

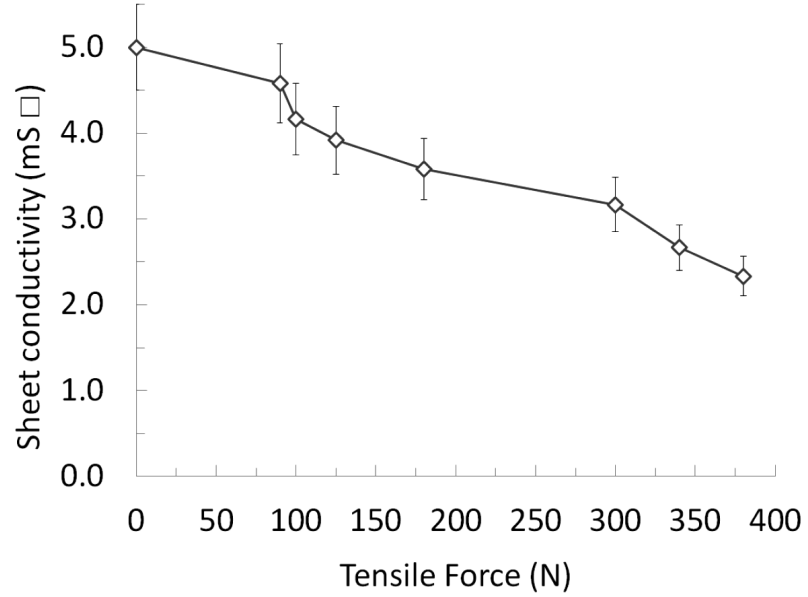

Figure 10: Sheet conductivity vs. strain force for cotton canvas with 14 layers measured at $12 \mathrm{~V}$

The results of the sheet conductivity measurements at tensile stress showed that despite the load the electrical conductivity is still present and consequently the heating of textile samples is still enabled.

After the applied tensile load, we examined the cotton material in detail and found that some defects in the material could be observed, while the basic functionality of the materials stayed unchanged.

\subsubsection{Heating rate}

To test the heating rate a constant voltage was applied to the cotton canvas textile with 14 printed layers. Figure 11 represents the diagram of temperature vs heating time where sample was heated with $24 \mathrm{~V}$ at approximately $120 \mathrm{~mA}$. The temperature was measured at 6 different points on the surface of the sample as a function of time and the plotted temperature is the average of all 6 measured points. The temperature of $50{ }^{\circ} \mathrm{C}$ can be achieved within 2 min with an approximate heating rate of $15{ }^{\circ} \mathrm{C}$ per minute. Using the reported condition the heating did not reach the temperature saturation, so some kind of temperature controller should be used to prevent

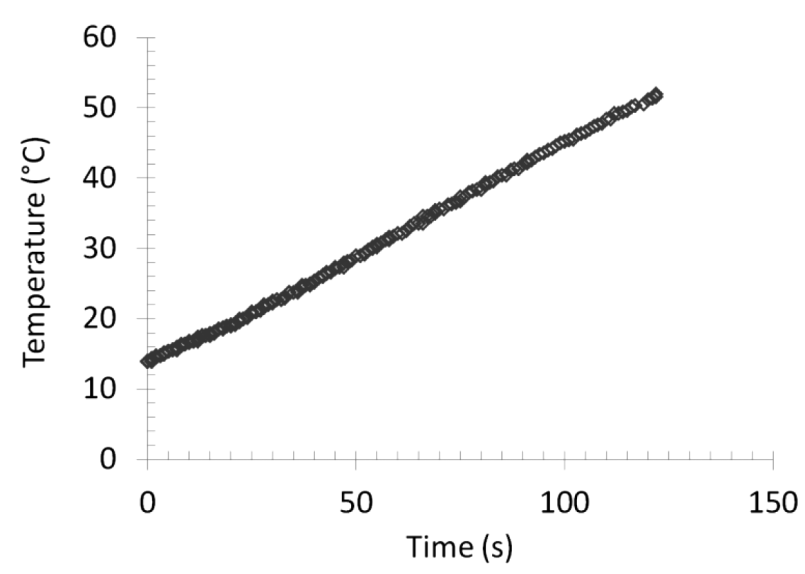

Figure 11: Average temperature vs. time measured with 6 uniformly distributed sensors on the surface of the cotton canvas sample with 14 layers. Heating current was $120 \mathrm{~mA}$ at $24 \mathrm{~V}$ 

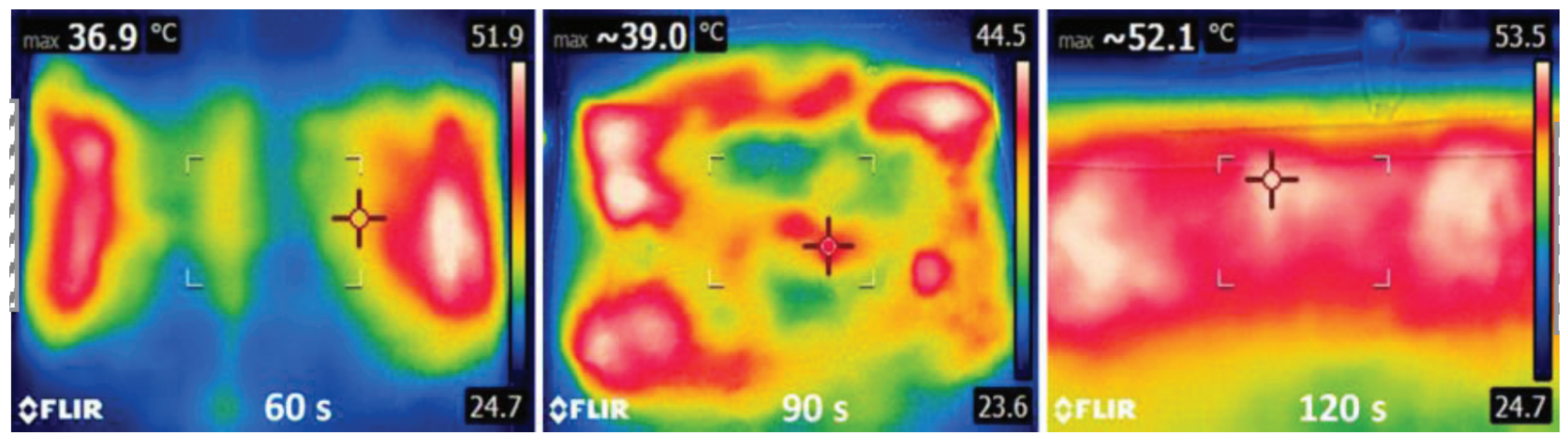

Figure 12: Temperature distribution during the heating (time in seconds) observed with an IR camera. Sample of cotton canvas $(20 \mathrm{~cm} \times 20 \mathrm{~cm})$ with 14 SWCNT-based layers was heated using $24 \mathrm{~V}$ and electrical current of $130 \mathrm{~mA}$. Electrodes, made of two 10-cm-long copper ribbons were positioned from the sides, as schematically shown in the image.

overheating. Using screen- or inkjet-printing techniques temperature sensors could be printed directly to the heating surface and used as a feedback for the temperature control unit. ${ }^{21}$

\subsubsection{Temperature distribution on heated area}

One of the important parameters in the potential practical use of this type of heating textile is the uniformity of the temperature on the surface. Using calibrated IR camera the temperature gradients on the surface of cotton canvas sample during the heating procedure was studied.

From the IR images of the surface (Figure 12) we followed the gradual heating of the samples. At the first stage of heating the distribution is not uniform, the sample started to heat intensively near the electrical contacts, in the intermediate stage the peak temperatures are starting to reach the interior of the sample and at the final stage the temperature is more-or-less uniform (within a few ${ }^{\circ} \mathrm{C}$ ) in the heated area. Based on the results of these experiments, we concluded that it is important that the electrical contacts (electrodes) are large enough and extending across the edges of the whole sample.

\section{DISCUSSION}

To lower the overall consumption of energy in electric cars, more efficient seat-heating systems than metal-wires-based discrete heating elements used today is needed. Using heating fabric in direct contact with the driver or passengers would be more efficient due to lower heat capacity, better thermal conductivity and lower working temperature. The main idea of the work was to screen print highly electrically conductive composite layer based on carbon nanotubes on the back surface of commercially used fabrics. Such coatings should enable good electrical contact, even during tensile strain of the fabric. As the base fabrics we used three commercially available materials, i.e., genuine leather, cotton canvas and artificial leather, which are normally used in the car industry.
Literature data show suitable conductivity in multiwalled CNT-epoxy composite films to heat a 7- $\mu \mathrm{m}$-thick composite to around $100{ }^{\circ} \mathrm{C}$ using voltages up to $90 \mathrm{~V} .{ }^{22}$ In car applications the usual voltage used is $12 \mathrm{~V}$ or $24 \mathrm{~V}$, so the conductivity reported in the literature is not high enough. To increase the conductivity we added highly conductive polyaniline fibers. ${ }^{17}$ The thickness and specific conductivity of the composite coating was tailored in the way that using these two voltages the temperature achieved would be in the range of $30-50{ }^{\circ} \mathrm{C}$.

The results from the microstructural investigation revealed that coatings have some degree of porosity (Figures 4 and 5) that would enable gas permeability (breathability) and that SWCNT are arranged in interconnecting curved bundles that would conduct electricity, even when stretched, which we confirmed with the experiments presented in Figure 9 and Figure 10. The thickness of the coatings depends on the number of screen-printed layers (Figure 6) and influenced strongly the specific electrical conductivity of the fabric. The relation between the number of coatings and the electrical conductivity under a constant potential of $24 \mathrm{~V}$ obeys a percolation model, where 8 coatings were found to be the percolation threshold (Figure 7). All three fabrics used with optimized conductivity exhibit a linear dependence between the electrical current and the voltage used (Ohm's law, Figure 8).

A $10 \times 20 \mathrm{~cm}$ area of a $20 \times 20 \mathrm{~cm}$ sample with an approximate mass of $15 \mathrm{~g}$ could be heated from $15{ }^{\circ} \mathrm{C}$ to $50{ }^{\circ} \mathrm{C}$ within 2 min with a uniform heating rate of $15^{\circ} \mathrm{C}$ per minute at $120 \mathrm{~mA}$ current (Figure 10). This means around $2.5 \mathrm{Wh}$ of electrical energy is needed to heat $1 \mathrm{~m}^{2}$ of cotton canvas fabrics, which is approximately the contact area of all car seats in a compact car. The surface temperature distribution during the first minute of heating is not uniform, the most heated areas are in the vicinity of the electrical contacts, but after two minutes of heating the temperature distribution is relatively uniform, within a few degrees centigrade (Figure 12).

For practical use, new materials in the car industry have to conform to strict regulation, such as low flammability (determination of this property is described 
for instance in ISO 3795 standard) and low toxicity. Because the basic material used in the study already meets the requirements of such regulations and the additional highly electrical conductive coating is added in very small quantities (less than $0.5 \mathrm{w} / \%$ in areas where it is applied) we can assume that the flammability of the whole fabric will not increase. Besides that, there are literature data showing that the composite where the matrix polymer used was poly(methylmethacrylate) (PMMA) with the addition of just $0.5 w / \%$ of SWCNTs exhibits lowering of flammability in terms of heat release rate (HRR) by around $50 \% .^{23}$

Although systematic studies of single-walled CNTs' toxicity are still lacking ${ }^{24}$ there are undoubted proofs that carbon nanotubes are toxic to humans and animals. In this sense the synthesis procedure was chosen in a way that a suspension of SWCNT is used (to minimize the airborne nanoparticles) and for the potential commercial use of the heating fabrics based on carbon nanotubes some additional protective layer should be used.

\section{CONCLUSIONS}

The composite fabrics of genuine leather, cotton canvas and artificial leather were coated on the back side with single-wall carbon nanotubes (SWCNTs) and polyaniline-fibres-based coatings by screen-printing as a potential electrical heating element used for automotive applications. It was found that at least 10 layers of coatings should be applied to the surface to exceed the percolation threshold with a total thickness of around $2 \mu \mathrm{m}$. From the SEM images we concluded that the SWCNTs were uniformly distributed over the surface, forming criss-crossed bundles enabling suitable electrical conductivity also in stretched material under tensile forces. Using moderate voltages and electrical currents (typically 12-24 V and 50-150 mA) we were able to heat the samples to $50{ }^{\circ} \mathrm{C}$ within two minutes. The material has a great potential to be used in car seats as a heating fabric. Comparing to classic discrete metal or carbon wire heating elements, such fabric will more uniformly heat the body contact seat areas, will have much lower heat capacity and will consume less electrical energy, which is a critical parameter in batterydriven vehicles. The aim of this work was to prove the concept of direct application of heating layers on the bottom of fabrics used in automotive applications. Before the practical use of the material the potential mechanical damage and toxicity due to wear should be solved with additional protective layers. To control the desired temperature, additional electrical control units should be developed, possibly with the integration of fabric with printed temperature sensors.

\section{Acknowledgement}

Authors wish to thank assist. prof. dr. Dunja Sajn Gorjanc from University of Ljubljana, Faculty of Natural Sciences and Engineering, Department of Textile, Graphics and Design for the mechanical testing of the fabric materials. Financial support from Slovenian Research Agency (ARRS) under the program P2-0393 is gratefully acknowledged.

\section{REFERENCES}

${ }^{1}$ H. Kezhen, J. Wu, T. Schwanen, Differences in Energy Consumption in Electric Vehicles: An Exploratory Real-World Study in Beijing, Journal of Advanced Transportation (2017) Article ID 4695975, 17 pages, doi:10.1155/2017/4695975

${ }^{2}$ V. Koncar, C. Cochrane M. Lewandowski F. Boussu, C. Dufour, Electro-conductive sensors and heating elements based on conductive polymer composites, International Journal of Clothing Science and Technology, 21 (2009) 2/3, 82-92, doi:10.1108/ 09556220910933808

${ }^{3}$ G. Weiss, P. Schleiss, C. Drabek, Towards Flexible and Dependable E/E Architectures for Future Vehicles, Matthieu Roy, $4^{\text {th }}$ International Workshop on Critical Automotive Applications: Robustness \& Safety (CARS 2016) (2016) Göteborg, Sweden

${ }^{4}$ S. Quanten, K. Janssens, P. McKenna, P. C. Young, D. Berckmans, Measurement and analyses of the thermal micro-climate in cars. Proceedings of the 9th International Conference on Indoor Air Quality and Climate, Monterey, CA. (2002) 701-706

${ }^{5}$ Y. F. Zhang, D. P. Wyon, L. Fang, A. K. Melikov, The influence of heated or cooled seats on the acceptable ambient temperature range, Ergonomics, 50 (2007) 4, 586-600, doi:10.1080/ 00140130601154921

${ }^{6}$ P. Ilanchezhiyan, A. S. Zakirov, G. Mohan Kumar, Sh. U. Yuldashev, H. D. Cho, T. W. Kang, A.T. Mamadalimov, Highly efficient CNT functionalized cotton fabrics for flexible/wearable heating applications, RSC Advances, 5 (2015), 10697-10702, doi:10.1039/ c4ra10667a

${ }^{7}$ T. Kim, D. D. L. Chung, Carbon fiber mats as resistive heating elements, Carbon, 41 (2003), 2427-2451, doi:10.1016/S00086223(03)00288-4

${ }^{8}$ Z. Motaghi, S. Shahidi, Effect of Single Wall and Carboxylated Single Wall Carbon Nanotube on Conduction Properties of Wool Fabrics, Journal of Natural Fibers, 12 (2015), 388-398, doi:10.1080/15440478.2014.945225

${ }^{9}$ H. Aniolczyk, K. M. Koprovska, Application of Electrically Conductive Textiles as Electromagnetic Shields in Physiotherapy, Fibres \& Tekstiles in EasternEurope, 12 (2004) 4, 47-50

${ }^{10}$ H. C. Chen, K. C. Lee, J. H. Lin, Comparison of Electromagnetic Shielding Properties of Diverse Conductive Textiles Via Various Measurement Techniques, Journal of Materials Processing Technology, 192-193 (2007), 549-554, doi:10.1016/j.jmatprotec. 2007.04.023

${ }^{11}$ K. Chu, D. J. Yun, D. Kim, H. Park, S. H. Park, Study of electric heating effects on carbon nanotube polymer composites, Organic Electronics, 15 (2014) 11, 2734-2741, doi:10.1016/j.orgel.2014. 07.043

${ }^{12}$ T. W. Lee, M. Han, S. E. Lee, Y. G. Jeong, Electrically conductive and strong cellulose-based composite fibers reinforced with multiwalled carbon nanotube containing multiple hydrogen bonding moiety, Composites Science and Technology, 123 (2016), 57-64, doi:10.1016/j.compscitech.2015.12.006

${ }^{13}$ K. Kalaitzidou, H. Fukushima, L. T. Drzal, A Route for Polymer Nanocomposites with Engineered Electrical Conductivity Percolation Threshold, Materials, 3 (2010), 1089-1103, doi:10.3390/ ma3021089 
${ }^{14}$ P. C. Ma, N. A. Siddiqui, G. Marom, J. K. Kim, Dispersion and functionalization of carbon nanotubes for polymer-based nanocomposites: a review, Composites Part A: Applied Science and Manufacturing, 41 (2010) 10, 1345-1367, doi:10.1016/j.compositesa. 2010.07 .003

${ }^{15}$ Z. Ounaies, C. Park, K. Wise, E. Siochi, J. Harrison, Electrical properties of single wall carbon nanotube reinforced polyimide composites, Compos Sci Technol, 63 (2003) 11, 1637-16746, doi:10.1016/S0266-3538(03)00067-8

${ }^{16}$ K. H. Baloch, N. Vosskanian, B. Merijntje, J. Cumings, Remote Joule heating by a carbon nanotube, Nature Nanotechnology, 7 (2012), 316-319, doi:10.1038/nnano.2012.39

${ }^{17}$ G. MacDiarmid, J. C. Chiang, A. F. Richter, A. J. Epstein, Polyaniline: A new concept in conducting polymers, Synth. Met., 18 (1987), 285-290. doi:10.1016/0379-6779(87)90893-9.

${ }^{18}$ J. Heeger, A. G. MacDiamid, H. Shirakwa, Macromolecules, American Chemical Society, 35 (2002) 4, 1137-1139, doi:10.1021/ ma0118973

${ }^{19}$ M. Zahid, E. L. Papadopoulou, A. Athanassiou, I. S. Bayer, Strain-responsive mercerized conductive cotton fabrics based on PEDOT:PSS/graphene, Materials \& Design, 135 (2017), 213-222, doi:10.1016/j.matdes.2017.09.026
${ }^{20}$ K. Kendall, K. N. G. Fuller, J-shaped stress/strain curves and crack resistance of biological materials, J. Phys. D. Appl. Phys. 20 (1987), 1596, doi:10.1088/0022-3727/20/12/008

${ }^{21}$ S. Bielska, M. Sibinski, A. Lukasik, Polymer temperature sensor for textronic applications. Materials Science and Engineering B, 165 (2009) 1-2, 50-52, doi:10.1016/j.mseb.2009.07.014.

${ }^{22}$ F. X. Wang, W. Y. Liang, Z. Q. Wang, B. Yang, L. He, K. Zhang, Preparation and property investigation of multi-walled carbon nanotube (MWCNT)/epoxy composite films as high-performance electric heating (resistive heating) element, Express Polymer Letters, 12 (2018) 4, 285-295, doi:10.3144/expresspolymlett.2018.26

${ }^{23}$ T. Kashiwagi, F. Du, K. I. Winey, K. M. Groth, J. R. Shields, S. P. Bellayer, H. Kim, J. F., Douglas Flammability properties of polymer nanocomposites with singlewalled carbon nanotubes' dispersion concentration, Polymer, 46 (2005), 471-481, doi:10.1016/j.polymer. 2004.10.087

${ }^{24}$ M. Ema, M. Gamo, K. Honda, A review of toxicity studies of single-walled carbon nanotubes in laboratory animals, Regulatory Toxicology and Pharmacology, 74 (2016), 42-63, doi:10.1016/ j.yrtph.2015.11.015 